\title{
Africa Game Changer: AfCFTA Broaden African Existing Partnership
}

\author{
Ehizuelen Michael Mitchell Omoruyi* \\ Center for Nigerian Studies at the Institute of African Studies, Zhejiang Normal University, China
}

The African Union agreed in January 2012 to develop the African Continental Free Trade Area (AfCFTA). It took eight rounds of negotiations, beginning in 2015 and lasting until December 2017, to reach an agreement. This is a historic pact which has been almost four decades in the making, and it represents a major progress for African integration and unity. The AfCFTA was signed by 44 African nations in Kigali on March 21, 2018, under the theme: "Creating one African Market", and if all African nations come on board, it will bring together over 1.2 billion people and $\$ 4.2$ trillion in combined consumer and business spending, according to Brookings. Also, Brookings report estimated that by 2030, Africa may emerge as a \$2.5 trillion potential market for household consumption, up from $\$ 1.1$ trillion in 2015 . It would then be the world's largest free trading bloc since the establishment of World Trade Organization (WTO) on January 1, 1995. The establishment of such a continent-wide trade area is one of the 12 flagship projects of the AU's Agenda 2063, Africa own development vision piloted by African Union. The agreement is anticipated to raise intra-African trade, which is still lower than trade between African countries and the outside world, by 55 percent by 2022 . Africa's exports to the rest of the world are also projected to grow by 6 percent. AfCFTA will progressively eliminate 90 percent tariffs on intraAfrican trade and according to the United Nation Economic Commission for Africa, this could boost intra-Africa trade by 53.2 percent. The removal of tariffs will create a continental market that will permits firms to benefit from economies of scale. Intra-continental trade in Africa is around 16 percent as against 21 percent in Latin America and Caribbean, 51 percent for Asia, and 70 percent for Europe.

The AfCFTA aims to change that, dealing with problems that include local business laws, security, and poor infrastructure. AfCFTA is expected to generate growth that could support economic diversification, of African economies away from low-value-added products and commodities as well as the development of regional value chains with considerable upgrading potential. Also, the continent will now be in a better position to negotiate the terms of trade and offer much more diversified export goods to international markets. Currently, Africa mostly trades in raw materials with China, for instance, and imports of manufactured goods from China, therefore since the AfCFTA's developmental approach is solidly grounded in Africa's political economy realities and development challenges, then increased local trade would boost the continent's export power and diversification. AfCFTA is anticipated to upsurge GDP between 1 percent to 6 percent, broadening the tax base and boosting revenue collection from other sources. The most important and urgent action involved would be providing the necessary infrastructure and creating the fiscal space required to foster both public and private investment while ensuring economic diversification with the view to creating jobs. The promise of free trade and free movement is prosperity for all Africans, because Africa is prioritizing the production of value-added goods and services that are "Made in Africa". The AfCFTA is expected to broaden the existing partnership between Africa and its partners. Africa expects to have a win-win situation with its partners through the African Continental Free Trade Area (AfCFTA). With the continental free trade area, both Africa and its partners will have a much bigger market and benefit all. Until now, the African external partners, China and others have good relations with Africa. African and the external partners will be able to work together on the AfCTFA because Africa will be in a position to share the growth brought by the AfCFTA with external partners, in particular with China. The picture is not of a continent that less than 130 years ago had no artificial boundaries and where its people traded and migrated freely. The African Union has embarked on an initiative that is ambitious but also necessary for upgrading China-Africa trade cooperation.

The signing of the AfCFTA comes as Africa is preparing for the Forum on China-Africa Cooperation (FOCAC) Summit on September 2018. During the FOCAC meeting, new policies and measures promoting China-Africa cooperation will be discussed to align the African Union Agenda 2063 and the Belt and Road Initiative. This will provide an opportunity for both

*Corresponding author: Ehizuelen Michael Mitchell Omoruyi, Center for Nigerian Studies at the Institute of African Studies, Zhejiang Normal University, China, Tel: +234-802-354-5408

Accepted: January 12, 2019

Published online: January 14, 2019

Citation: Omoruyi EMM (2019) Africa Game Changer: AfCFTA Broaden African Existing Partnership. Insights Anthropol 3(1):130-131 
sides to upgrade China-Africa trade in order to promote the actualization of a community with a shared future between Africa and China. Since its formation in 2000, FOCAC has become a game-changer in Africa's development narrative. Africa's image has dramatically changed from the pessimism of a "hopeless continent" to the optimism of "Africa rising". This is partly as a result of China's heavy investment across Africa through dramatically augmented trade, foreign direct investments, and loans from the China Export-Import Bank, which have deepened cooperation in a wide spectrum of areas. As a result of the good relations between Africa and China, Africa can launch cooperation with China in this area. The bilateral trade between Africa and China has seen speedy growth recently. China customs statistics display that Africa-China trade was "off to a flying beginning" of \$170 billion in 2017. The trade volume increase by 19 percent as against the 18 percent fall in 2015 . The increase is propelled by the construction sector. Since 2013, China has been implementing the Belt and Road Initiative (BRI), enabling China to pump billions of dollars into infrastructure such as Kenya's monumental SGR Railway. The newly signed agreement to create the African Continental Free Trade Area (AfCFTA) is likely to bolster China's confidence in Africa as an investment destination and an emerging market. Also, Africa is likely to benefit from China's newly created international development cooperation agency designed to coordinate China's foreign aid programme.

In this context, African leaders and Chinese leadership are facing historic opportunities in bolstering their trade cooperation, which can help improved integrated and globalized development in Sino-Africa cooperation. Conversely, the trend of anti-globalization has happened in the global community with soaring trade protectionism. Therefore, it is essential for China to consider launching free trade agreement negotiations with African leaders. It is of great importance for Chinese leadership and African leaders to sign free trade agreements via negotiations. While negotiating free trade agreements, both sides could set detailed and feasible stipulations on trade in merchandises, particularly in the area of mutual worries like intellectual property and dispute settlements, tariff exemption, customs processes, and trade facilitation. This can assist in fostering China-Africa trade, African integration, boost development of globalization and actualize future common shared prosperity for both sides. Based on China's second Africa policy paper issued in December 2015, the Chinese leadership stated that "China will continue to support the development of the African Free Zone and regional integration, and discuss the creation of institutionalized trade agreements with African Union Members state". At the $30^{\text {th }}$ Ordinary Session of the African Union Summit, which was held from January 22nd to $29^{\text {th }}, 2018$ in Addis Ababa, Ethiopia. The ordinary session also noted that creating AfCFTA, promoting the formation of a single African air transport market and the free movement of people and merchandises are the three key measures for actualizing African integration. For that reason, it will make economic sense for African leaders to accelerate their free trade agreement negotiations in order to foster sustainable development for the continent of Africa.
It makes economic sense for China and Africa to pursue stronger regional trade agreements which in turn can help form the building blocks for both sides' free trade deals. Also, it can help further enhance the African regional market and promote transformation as well as upgrade Africa-China trade cooperation. Increasing trade will not only help both sides economies develop but also drive growth around the world as the financial crisis recedes. At present, Africa trade with China is based on bilateral trade agreements, and Chinese leadership is yet to reach any concrete free trade agreements with African leaders. Free trade agreements between Chinese leaders and African leaders can be of huge advantage to both parties, assisting China's merchandises to go into African markets freely. China and African leaders should realize that if both sides can reach a free trade agreement, both sides could greatly expand their markets and in turn help, Africa bolstered its economic cooperation globally. China and Africa should also know that through institutional trade agreements with regional organization in Africa, such as the Arab Maghreb Union (AMU/UMA) in the north, the Economic Community of West African States (ECOWAS) in the west, the East African Community (EAC) in the east, the Intergovernmental Authority on Development (IGAD) in the east, the Southern African Development Community (SADC) in the south, the Common Market for Eastern and Southern Africa (COMESA) in the southeast, the Economic Community of Central African States (ECCAS) in the center, and the Community of Sahel-Saharan States (CENSAD) in the north, Sino-Africa trade will be more balanced and stable.

The international community stresses the launching of investment and trade with African nations and regions via economic and trade arrangements as a free trade agreement. For example, the European Union (EU) launched a series of negotiations on economic partnership agreements with African regional organizations like SADC, EAC, ECOWAS and the West African Economic and Monetary Union (UEMOA). The agreements signed by EU and EAC and SADC went into effect in June and October 2016, respectively. The EU and 16 members of ECOWAS and UEMOA have reached pact on the contents of the economic cooperation pact. The United States also signed the same pacts with some regional organizations in Africa. These pacts stipulated detailed arrangements on market access, trade, and related matters. In the same way, Chinese leadership should consider launching a free trade pact with African leaders in order to enhance the partnership between Africa and the world. The Chinese leadership can begin by considering launching negotiations with the various abovementioned regional organizations. The signing of AfCFTA means African Union want to achieve Agenda 2063 by encouraging intra-trade and promoting the unified market. African leaders broadly see China as a healthy counterbalance to Western influence but, as ties mature, there are rising calls from policymakers and economists for balanced trade cooperation. In order to further expand China-Africa trade, Chinese leadership can consider launching free trade negotiations with the various abovementioned African regional organizations and AfCFTA. 